AperTO - Archivio Istituzionale Open Access dell'Università di Torino

'Who is in Your Family?' Italian Children with Non-heterosexual Parents Talk about Growing Up in a Non-conventional Household

This is a pre print version of the following article:

Original Citation:

Availability:

This version is available http://hdl.handle.net/2318/1547477

since 2016-03-30T14:00:17Z

Published version:

DOI:10.1111/chso.12148

Terms of use:

Open Access

Anyone can freely access the full text of works made available as "Open Access". Works made available under a Creative Commons license can be used according to the terms and conditions of said license. Use of all other works requires consent of the right holder (author or publisher) if not exempted from copyright protection by the applicable law. 


\title{
'Who is in your family?' Italian Children with Non-heterosexual Parents Talk about Growing Up in a Non-conventional Household
}

Roberta Bosisio and Paola Ronfani

\begin{abstract}
The paper presents findings from explorative research conducted in Italy with seven 9- to 12-year-old children with non-heterosexual parents. The aim was to find out how children describe their family structure, how they talk about their family with peers, and how they experience peers' attitudes toward non-heterosexual families. Findings show that children have a flexible and inclusive representation of family and they disclose selectively with their peers who don't always consider homosexuality normal and homoparental families "real families".
\end{abstract}

\section{Introduction}

What we know about children with homosexual parents thus far (especially about children born in lesbian-headed families) comes mostly from research conducted in the US and the UK in the area of psychology. These studies aimed at evaluating the adequacy of children's development and the quality of parenting using psychological tests, psychometric techniques and standardized interviews and questionnaires. Findings from this research show that in the presence of same-sex parents, there was no deficit in cognitive and social adjustment, in development of sexual orientation and identity or in the quality of parenting (Bos and others, 2015; Golombok and Badger, 2010; Tasker, 2010). Moreover, some research found that children with two mothers enact less gender-stereotyped behaviours, attitudes and preferences; enjoy greater emotional well-being; and show fewer social and behavioural problems than their peers who have grown up in heterosexual parent families (Anderssen and others, 2002; Gartrell and others, 2005; Bos and Sandfort, 2010).

Very little research focuses on children's views on growing up with two mothers. This limited research was done with children in planned lesbian families using qualitative interviews and drawings, and investigates how children describe their 
network of family relationships and the role of the non-birth mother, how they introduce their family to their peers and talk about the absence of a father and about the donor.

Findings from these studies show that children with same sex-parents usually have a more inclusive and flexible concept of family and that those in planned lesbian-headed families include the two mothers, siblings and pets in their family (Malmquist and others, 2014) while the inclusion of the known donor in the family depends on his level of involvement in parental practices (Tasker and Granville, 2011).

With respect to coming out with peers, children spontaneously disclose only with close friends (Vanfraussen and others, 2002; Gartrell and others, 2005; Lubbe, 2008), performing what Bozett (1989) defines as "selective disclosure."

Moreover, a majority of children with lesbian mothers enjoy positive relationships with peers (Leddy and others, 2012), and do not seem to be teased more than children with heterosexual parents. The difference consists in the fact that they are sometimes teased about their family configuration, something that does not happen to children with a mother and a father (Vanfraussen and others, 2002).

Finally, a minority have to deal with stigmatization and homophobia on the part of some companions, engendering psychological suffering and behavioural problems in some cases (Gartrell and others, 2005; Bos and others, 2008; Fairtlough, 2008; Robitaille and Saint-Jacques, 2009).

\section{Same-sex Parent Families in Italy}

Differently from situations abroad, studies on same-sex parent families are fairly recent in Italy (Bonaccorso, 1994; Danna, 1998; Allegro, 2006; Lalli, 2008; Cavina and Danna, 2009; Bertone, 2010; Dèttore and Parretta, 2013; Bastianoni and Baiamonte, 2015). The reason may be traced to their statistical and institutional invisibility. Regarding statistical invisibility, up to the present moment, there are no reliable figures on their numbers. Only the last 2011 Census included a question to detect cohabiting homosexual couples. According to the Census data, there are only 
7,513 cohabiting homosexual couples in Italy, of which 529 have children (ISTAT, 2014). It is believed that this data does not fully reflect the phenomenon. It is plausible that many couples decided not to make their family configuration known publicly through an instrument that is perceived as official. Findings from research done by Arcigay (2005) - the Italian gay rights organisation - on a sample of about 10,000 homosexual and heterosexual people would confirm this opinion. This research indicates that $20 \%$ of lesbians and $18 \%$ of gays over 40 have at least one child, and estimates that 100,000 children in Italy are being raised by homosexual parents.

As for institutional invisibility, Italy - together with Greece and a few other countries in Europe - does not legally recognize either heterosexual or homosexual cohabiting couples, or social filiation (the legal relationship connecting a child to her mother or father) with reference to stepfamilies. Moreover, surrogacy and heterologous artificial fertilization are not allowed, nor is adoption on the part of homosexuals permitted. Regarding heterologous fertilization, it must be stressed that last April, decision 162/2014 of the Constitutional Court declared illegitimate such a ban, in that it is discriminatory. Furthermore, a bill is currently under discussion in Parliament (DDL n. 14) about civil unions that also includes homosexual couples.

The lack of legal recognition of same-sex parent families can be ascribed to various reasons. To begin with, the belief that children need a father and a mother to grow up without creating a deficit in their psychological, social and sexual development (Wardle, 1997; Cigoli and Scabini, 2008; Winter, 2010; Risé, 2013). Secondly, we can assume that in Italy there is still a homophobic orientation. On this point, it should be noted that Italy still has no law against homophobia. The third reason is due to the influence of the ecclesiastical hierarchy on public opinion and politicians in order to defend the family based on heterosexual marriage (Barbagli and others, 2010). Concerning the Italian opinion on homosexual couples and parenting, data showed that regarding homosexual cohabitation, the percentage of people saying that they are in favour increased from 39\% in 1993 to 63\% in 2011, while the percentage of those in favour of adoption by homosexual couples was $14 \%$ in 1993 and reached only 21\% in 2011 (Barbagli and Colombo, 2007; ISTAT, 2012). 
Nevertheless, findings from the few studies conducted in Italy on same-sex parents - more specifically, lesbian mothers - have substantially confirmed the results of research conducted abroad on children's well-being: their children do not experience specific educational problems and cases of discrimination are few. On the contrary, homosexual parents experience clear difficulties in relationships with institutions because of marginalization on the part of the law and politics (Cavina and Carbone, 2009; Danna, 2009).

\section{Research Design}

In the article, we present some findings from explorative research conducted with same-sex parents and co-resident children, and children with homosexual parents. Findings from the study with both homosexual parents and children were published in AUTHORS (XXXX). Here, we focus only on some findings from focus groups (FGs) with children.

The goal of the research is to better understand the daily life of children with same-sex parents. More specifically, the aim is to detect how children describe their family structure and how they present their family to peers.

The study is of considerable importance because of the lack of research in this field involving children (Goldberg, 2010; Malmquist and others, 2014) and the specificity of the Italian context, where a) homoparental families do not enjoy any recognition on the part of the institutions and, above all, b) no study has observed children's views about growing up with homosexual parents.

The research is based on the social-constructionist approach that recognises families as socially constructed (Dunne, 2000) and is in line with childhood studies in which children are viewed as social actors whose voices and opinions should be heard in order to understand their lived experiences from their own perspective, which can differ from those of adults (Kellett, 2005).

To explore children's experience of living with homosexual parents, we conducted two FGs with children aged 9-12 living in Central and Northern Italy. We used a qualitative research method because it allows participants to describe their views and feelings and is appropriate for the investigation of sensitive topics, 
vulnerable people and potentially stigmatised groups. Moreover, we decided to involve children in FGs instead of interviewing them individually because this method reduces the imbalance in power between the researcher and the participants, because it allows children to express their perceptions and experiences "in their own words," and stimulates the exchange of opinions between participants (Derbyshire and others, 2005; Liamputtong, 2007).

In order to conduct the FGs, we developed an interview guide. The questions were chosen to be as open as possible and aimed at investigating: the composition of the family; how they talk about their family configuration in interaction with peers; and finally, how they experience peers' attitudes toward non-heterosexual families.

As has been highlighted in other studies done abroad (Rosenfeld, 2010), samesex parent families are a difficult population to study in a systematic way because of their scarce number, geographical dispersion and low visibility. To overcome the latter two problems, we thought that the annual meeting of Famiglie Arcobaleno would be the best occasion for bringing together in the same place an adequate number of children with whom to conduct the FGs. Famiglie Arcobaleno (www.famigliearcobaleno.org) is the most important Italian organization specifically dedicated to recognizing the rights of same-sex parent families. It represents around 400 families and 200 children, most of whom were conceived within a same-sex relationship.

The research shares the limitations of other studies on LGBT families done using a volunteer sample that was recruited through an association, that is, the problem of underrepresentation of some parts of the population (those from a lower socioeconomic and cultural background and minorities) (Goldberg, 2010; Moore, 2011). We are aware that socio-cultural contexts affect the experience of homosexual parents and their children (Gabb, 2004), but such limits, linked to the method of gathering samples, are hard to overcome in those countries where marginalization persists due to the enduring stigmatization of homosexuality.

In accordance with Italian law 391/2006, we asked for parental consent for the children's involvement and we also explained to the children that it was their own free choice to participate or not. Because of the age homogeneity, only seven 
children were involved in the FGs, of whom none had two fathers. As a matter of fact, in Italy only recently have gay couples begun to realize their dream of becoming parents. For this reason, their children are still very young.

The FGs were conducted in 2012 by AUTHOR. They were audio-taped, transcribed verbatim and thematically analysed. Due to the low number of participants in each group, FGs "tended towards a serial interview" and unfortunately discussion between participants was limited (Morgan and others, 2002). For this reason, sometimes we reported the quotations of children's words mixing children from the two FGs.

The first FG involved four 9-year-old children (3 females and 1 male); three of them were born in planned lesbian families through donor insemination (DI), and one in a joint parenting arrangement between a lesbian couple and a gay couple. The second FG was done with three 11- to 12-year-old children (2 females and 1 male) respectively born in a planned lesbian family through DI; in a joint parenting arrangement between a lesbian and a gay couple; and in a heterosexual marriage before the father adopted a gay identity (Tab. 1).

All the children belong to families from a medium-high socio-economic background: all the parents are regularly employed in high-level jobs and hold high educational qualifications.

\section{Findings from the Study}

\section{"Who is in your family?" Children's Representation of Their Family}

Except for the young girl conceived in a heterosexual relationship, all the children say their family is composed of two mothers, to which the father is added in the case of two sisters born in the context of a joint parenting arrangement, siblings (also born through DI), and possible pets, confirming findings of already mentioned research performed abroad.

Who is in your family, Alessio? ALESSIO: My 12 year old brother, my 9 year old sister, Lela and Chicca. So you have a brother and a sister. And who are Lela and Chicca? ALESSIO: Mommy and mommy. And that's it? Is that everyone in your family? ALESSIO: No no... I've got four cats.

Who wants to talk about who is in their family? 
MARTA: I have two mothers, who have been together for 20 years, and then there's my little brother and my older brother. And then we have four cats.

FRANCESCA: I have two mommies. One is named Roberta and the other one is named Alessandra. I have a dad and his name is Antonio, but I call him Baba, and I have a sister. And I have a dog.

Do you live all together?

No, my dad lives in another house. I live with my sister, my two mommies and the dog

(...)

What do you call your mothers and dads?

FRANCESCA: I call my father Baba, one of my mothers Ami and the other "mommy."

And you, Alessio?

ALESSIO: I usually call them "mommy."

And how do they know who you mean? Both of them will answer you!

ALESSIO: No, no, no. Usually, if they're both there, they'll say: "Which mommy?" or after a while that I'm saying "mommy, mommy" I use their names.

And do you do that as well?

FRANCESCA AND MARTA: Noo.

SOFIA: No! Whoever comes, comes.

MARTA: You [Sofia] didn't tell us yet about your family.

SOFIA: So... there's a little baby... There are the twins, and then there's me, and then there's three cats... and two mothers. The end.

Despite the fact that some research stresses the awkwardness of the children because of the lack of vocabulary to indicate the non-birth mother and her role (Gabb, 2005; Perlesz and others, 2006), overall, in our research, children with two mothers do not seem express the need for terminology to distinguish the biological mother from the non-birth mother. All the children conceived by DI, except for the two sisters born in the joint parenting arrangement, call both mothers "mommy," to which they sometimes add the first name when necessary.

It would appear that in their representation of the family and parenting, the genetic and biological aspects hold no importance for the children. These aspects, however, are at the centre of the adult debate, in cultural and academic circles (Gambino, 2007; Nordqvist and Smart, 2014).

LUCIA: My biological mom is Roberta, she gave birth to me, but I don't consider Roberta more of a mother. There's no difference (...) Obviously, I don't have preferences about my parents, it never even occurred to me who I preferred, who is more my mother.

This finding confirms what other research on the opinions of children with samesex parents already showed. In fact, it underscored how the presence of biological ties in a family are not considered an indispensable element for family relations and kinship (Weston, 1991). Members of these families would use other criteria to 
define the nature and sense of family, and would show more ample margins of freedom in the choice of whom they include or exclude (Goldberg, 2010).

It is important to focus on the fact that all the children born by DI know how they were conceived. This is in fact a "process that all homosexual families manage with their own children, with a language and approach linked to the various phases of growth" (Taurino, 2012: 86; Lycett and others 2005; Nordqvist and Smart, 2014).

Mothers explained "their story" to them. They say their mothers decided to have a child because they love each other:

ALESSIO: One mother fell in love with the other one and vice versa. And so they asked a man for sperm and they made a baby.

LUCIA: My two moms got married, they wanted to have children and so they asked a friend of theirs.

In their experience, the biological element of conception and the social element of caretaking are not traceable to the same person. We can thus deduce that for these children, the parent is the person who concretely takes care of them, beyond a biological link, and that in their representations, parenting is constructed through caretaking: "the doing of parenting" (Gabb, 2005). In this sense, they contribute to deconstructing the primacy of the biogenetic connection as the fundamental element of kinship and family ties (Hargreaves, 2006).

That the children with two mommies have a functional idea of parenting is confirmed by the fact that they do not seem particularly interested in knowing "how" they were born.

You weren't curious to know how you were born?

FRANCESCA: Mmmh yes, but after a while I didn't care because I liked having two mommies and I knew that it was the same thing as having a dad and a mom.

We can conclude, then, that in the representation of children with two mothers including the two sisters born in a co-parenting project - the non-birth mother is to all effects the second parental figure, equal to the biological mother (Golombok and Badger, 2010).

\section{Peers' Reactions and Public Recognition}

One important process that children with same-sex parents undergo concerns the issue of disclosure. With respect to the opportunity of sharing or keeping secret the 
specific configuration of the family, there is no unanimous opinion among scholars: some believe that revealing that you were raised with parents of the same sex can provoke anxiety (Gianino and others, 2009), while others believe that it can provide relief from the weight of keeping a secret (Goldberg, 2007a).

When children start going to school, they have to deal with - usually for the first time - differences in family structures and answer peers' questions about their family configuration (Garner, 2004). In our research, as for children with two mothers, the most common situation is that of the perplexity of friends who live in conventional families when faced with a family where there are two mothers, having to explain to them in a "scientific" way how it happened that they were conceived because their friends don't know how babies are made.

ALESSIO: With me, they kept asking, "Why do you have two mommies?" (...) They were curious, let's say...

ALESSIO: They kept saying it to me but I didn't know how to tell them because they weren't very informed. Now anyway [in science class] we did sperm and eggs and so I could tell them in words that were more... I could explain in words they knew.

What did you tell them?

ALESSIO: That... I mean, one mother fell in love with the other one and vice versa. And so they asked a man for some sperm and they had a baby.

MATTIA: I remember that the first years of elementary school [my classmates] kept asking "How can you have two mothers? How can you?" And so every time I had to explain the same story.

What did you say?

MATTIA: That I had two moms... That my two mothers went to the hospital and they asked for a little seed and they got it, etc.

How old were you when you explained all this?

MATTIA: Six.

But they understood the story about the little seed?

MATTIA: Yes, but after ten minutes they'd ask again [they laugh]

You mean they knew how it worked? They already knew where babies come from?

MATTIA: No.

So maybe that's why they asked again.

MATTIA: Yes. But in middle school no one ever asked.

And do they know that you have two moms?

MATTIA:I think everybody knows.

In the FGs, it emerged without a doubt that the children living with two mothers were annoyed, bored and also strained from having to repeatedly explain the structure of their family because sometimes the peculiarity of the family provoked exclusion, teasing or scorn: 
When you started going to school...

SOFIA: They really gave me a hard time.

They gave you a hard time? Who?

SOFIA: My friends, they really gave me a hard time.

What do you mean?

SOFIA: My friends were really getting on my nerves. They said: "You can't play because you have two mommies, "It's better to have a dad because when your mom gets mad, he sticks up for you"... things like that.

And what did you say?

SofIA: What? Nothing.

But what did you do? Did you play anyway?

SOFIA: I played anyway. [she laughs.]

(...)

And you? How did it go with your friends?

MARTA: Well... I have a friend that everybody teases saying that he's married to a boy. I defend him because he's my best friend (...) and a little boy came up to me and said: "You have two mothers, you're disgusting!"

(...)

It seems Francesca also has a dad. What do you do, Francesca? They don't ask you why you have two moms and one dad?

FRANCESCA: Tons of times! Like: "How come you have two moms and a dad?" "I don't know." [they laugh]. No, actually usually I say... "That's my business!" That is, when I was small, I used to say "Go away, because it's my life, it's my story and so go away!"

MARTA: But you said that to them because you didn't know what your story was, or because you didn't want to tell them?

FRANCESCA: You already know! [offended]

MARTA: Because they would tease her then.

And now that you're older?

FRANCESCA: Well, they don't ask me anymore, but sometimes yes, and I... I don't know what to say.

MARTA: I don't care.

FRANCESCA: Exactly.

MARTA: ... and I say "Ciao, bye-bye!" [they laugh]

You don't give any explanation?

SOFIA: No.

Because... are you tired of hearing these questions all the time?

SOFIA: Yes, very tired of it.

FRANCESCA: But... there's no difference if you have one mother and one father. I mean, it's better like this. Once a boy came up to my sister and said, "Why do you have two moms and a dad?" Then another one came up - it was her best friend - and said, "Well, when one leaves you still have the other one."

SOFIA: You still have two parents!

When your friends asked you about your mom and your dad what did you say?

LUCIA: At school, ever since I was small, everyone knew, and frankly, I don't care what the others say, because it's my family and I love it anyway... I don't care what it's made up of. The important thing is that we love each other.

But for your friends, do you think it was a problem?

LUCIA: No. My friends... I mean, for example, in first grade I remember that a friend of mine was talking to me about her family and at a certain point she asked me, "What's your family like?" and I said, "Well, I have two mom and a dad," and she said,: "Wow! That's cool! I want two 
moms too! Having two moms is better than having a mom and a dad: when one mother is tired of putting me to bed, the other can do it!

As has emerged in other research done with adult children of LGB parents, children are committed to convincing friends that their family was a "real family", and they defend it when faced with the scepticism of friends. Moreover, they often strive to "educate others about the realities of growing up with a gay parent, as well as to correct harmful stereotypes" (Goldberg, 2007b, p. 555; Garner, 2004).

The little girl with the gay father seemed to be the one who most experienced "the pressures to conform to heteronormative standards" (Goldberg, 2007a, p. 123). She is the most insecure about schoolmates' reactions about her father's homosexuality and this is why she tends not to talk about it. This result seems to confirm a distinction between children raised by two mothers, who know their parents' sexual orientation from birth, and those who learned of the homosexuality of their parents in childhood: "Being raised by two gay parents from birth appears to be related to an enhanced sense of pride (...) which in turn was seen (...) as motivating disclosure" (Goldberg 2007a, p. 128).

Why do you want to keep your father's homosexuality a secret?

VIOLA: (...) Because in my class they would surely make fun of me. Of my friends, only my best friend knows [that my father is gay]. (...) if they make remarks [about homosexuality] I pretend I don't hear. Anyway [having homosexual parents] is something strange and so if they knew it, they would tease you. "It's not suitable or fitting, in the end," that's what they think! Or at least, that's what I think, that they don't see it as something to be proud of (...). They think that it is something that would make you say something like "I'm so unlucky." But they don't actually say it to me... what I mean is, my best friend doesn't say anything, but I think that she probably thinks like that. As for what I think, if my dad is gay, it doesn't change anything.

On the whole, the phrases reported above show that children carefully select the peers to whom to explain the special quality of their family, according to their own interpretation of the surrounding context (Goldberg, 2007a). They are aware that some peers do not consider homosexuality normal, or that their family structure is one of the many possible family configurations. Therefore, in some cases they talk about it openly, in other cases they give explanations only if specifically requested. And finally, in other cases they probably feel "threatened" and defend themselves with words like “That's my business!”, or comment: “I don't care”, or do not answer. 


\section{Some Reflections and Conclusions}

The voices of the children involved in our study, because of the small number and the limitations of the study reported above, should not be viewed as representative of family and children with non-heterosexual parents. However, the study contributes to reducing the lack of literature about children with same-sex parents. Moreover, it is the first investigation conducted in Italy with young children raised by same-sex parents aimed at investigating their opinions and representations of their experience of growing up in a non-conventional family and of disclosure with peers.

Findings show that children living with two mothers have an inclusive and flexible representation of family that goes beyond biological and genetic aspects. This does not mean that our interviewees born through DI are not aware of the position of the biological father within their own family genealogy. This is true both for children with two mothers and for those born in the joint parenting arrangement.

But the voices of the children we listened to also tell us how hard it sometimes is, in their daily life, to deal with social recognition and acceptance of their family within the relationships with their peers. Above all, they tell us about the difficulties they face to explain the way they were born, the homosexuality of their parents, and the hesitation that sometimes pushes them to silence. More generally, it is difficult to present their family as a "real family", because sometimes the image of same-sex parent families and of homosexuality as deviant phenomena is detectable among their peers.

Their more inclusive and flexible idea of family does not always encounter a positive response on the part of friends who more often than not show curiosity and an inclusive attitude, but who sometimes assume explicitly hostile and discriminatory behaviour. For this reason, they are often committed to presenting their family and parents as normal.

As a matter of fact, social institutionalization of unconventional families and forms of parenting that occur within them, can be enhanced by legally recognizing them as legitimate expressions of the plurality of family forms. This would represent 
a powerful message of equality in fact (Goldberg, 2010). On this point, research showed that in countries where homosexual unions and parenting are recognized by the law, the percentage of children with same-sex parents who are victims of homophobia, and potentially at risk of minority stress, is lower (Bos and others, 2008). On the contrary, the lack of recognition of these unions validates social prejudice and fosters discrimination and mechanisms of "social and internalized homophobia" (Cavina and Carbone, 2009, p. 44).

\section{References}

Allegro S. 2006. Le sfide della maternità lesbica: uno studio sui percorsi di coming out madre-figli. In Omosapiens. Studi e ricerche sugli orientamenti sessuali. Rizzo D (eds). Carocci: Roma; 43-54.

Anderssen N, Amlie C, Ytterøy Ea. 2002. Outcomes for Children with Lesbian or Gay Parents. A Review of Studies from 1978 to 2000. Scandinavian Journal of Psychology 43(4): 335-351. DOI:10.1111/1467-9450.00302

Arcigay. 2005. Survey nazionale su stato di salute, comportamenti protettivi $e$ percezione del rischio HIV nella popolazione omo-bisessuale. Report for the Italian Institute of Health.

Barbagli M, Colombo A. 2007. Omosessuali moderni. il Mulino: Bologna.

Barbagli M, Della Zuanna G, Garelli F. 2010. La sessualità degli italiani. il Mulino: Bologna.

Bastianoni P, Baiamonte C (eds). 2015. Le famiglie omogenitoriali in Italia. Relazioni familiari e diritti dei figli. Editori Junior: Parma.

Bertone C. 2010. Genitori e figli. Oltre la normatività esterosessuale. Un'esplorazione della ricerca, italiana e internazionale, sulle esperienze di genitorialità di lesbiche e gay e su quelle dei loro figli. Infanzia 2. Available at www.rivistainfanzia.it/archivio/2 2010/Bertone.html (accessed 7 September 2015).

Bonaccorso M. 1994. Mamme e papà omosessuali. Editori Riuniti: Roma.

Bos HMW, Gartrell NK, Balen F Van, Peyser H, Sandfort TGM. 2008. Children in Planned Lesbian Families: A Cross-Cultural Comparison between the United States and the Netherlands. American Journal of Orthopsychiatry, 78(2): 211-219. DOI: $10.1037 / \mathrm{a} 0012711$

Bos HMW, Sandfort T. 2010. Children's Gender Identity in Lesbian and Heterosexual Two-Parent Families. Sex Role, 62(1-2): 114-126. DOI: 10.1007/s11199-0099704-7

Bos HMW, van Gelderen L, Gartrell N. 2015. Lesbian and Heterosexual Two-Parent Families: Adolescent-Parent Relationship Quality and Adolescent Well-Being. Journal of Child and Family Studies 24(4): 1031-1046. DOI: 10.1007/s10826014-9913-8

Bozett FW. 1989. Gay Fathers: A Review of the Literature. Journal of Homosexuality 18(1-2): 137-162. DOI: 10.1300/J082v18n01_07 
Cavina C, Carbone R. 2009. L'eccezionale quotidiano: le famiglie con madri lesbiche. In Crescere in famiglie omogenitoriali. Cavina C, Danna D (eds). Franco Angeli: Milano; 43-63.

Cavina C, Danna D (eds). 2009. Crescere in famiglie omogenitoriali. Franco Angeli: Milano.

Cigoli V, Scabini E. 2008. Relazione familiare: il principio di cura. La Revue du REDIF 1: 23-28.

Danna D. 1998. Io ho una bella figlia. Le madri lesbiche raccontano. Zoe Media: Forlì.

Danna D. 2009. Madri lesbiche in Italia: il mito della discriminazione. In Crescere in famiglie omogenitoriali. Cavina C, Danna D (eds). Franco Angeli: Milano; 103116.

Derbyshire P, Macdougall C, Schiller W. 2005. Multiple Methods in qualitative research with children: more insight or just more? Qualitative Research 5(4): 417-436. DOI: 10.1177/1468794105056921

Dèttore D, Parretta A. (eds). 2013. Crescere nelle famiglie omosessuali. Un approccio psicologico. Carocci: Roma.

Dunne GA. 2000. Opting into Motherhood: Lesbians Blurring the Boundaries and Transforming the meaning of Parenthood and Kinship. Gender and Society 14(1): 11-35. DOI: $10.1177 / 089124300014001003$

Fairtlough A. 2008. Growing Up with a Lesbian or Gay Parent: Young People's Perspectives. Health and Social Care in the Community 16(5): 521-528. DOI: 10.1111/j.1365-2524.2008.00774.x

Gabb J. 2004. Critical Differentials: Querying the Contrarieties between Research on Lesbian Parent Families. Sexualities 7(2): 171-187. DOI: $10.1177 / 1363460704042162$

Gabb J. 2005. Lesbian M/Otherhood: Strategies of familial-linguistic management in lesbian parent families. Sociology 39(4): 585-603.

Gambino G. 2007. Le unioni omosessuali. Un problema di filosofia del diritto, Giuffrè: Milano.

Garner A. 2004. Families Like Mine: Children of Gay Parents Tell It Like It Is. HarperCollins: New York.

Gartrell N, Rodas C, Deck A, Peyser H, Banks A. 2005. The National Lesbian Family Study: 4. Interviews With the 10-Year-Old Children. American Journal of Orthopsychiatry 75(4): 518-524. DOI: 10.1037/0002-9432.75.4.518

Gianino M, Goldberg A, Lewis T. 2009. Family Outings: Disclosure Practices Among Adopted Youth with Gay and Lesbian Parents. Adoption Quarterly 12(3-4): 205228. DOI: $10.1080 / 10926750903313344$

Goldberg A. 2007a. Talking about family: Disclosure Practices of Adults Raised by Lesbian, Gay, and Bisexual Parents. Journal of Family Issues 288(1): 100-131. DOI: $10.1177 / 0192513 X 06293606$

Golberg A. 2007b. "(How) does it make a difference? Perspectives of adults with lesbian, gay and bisexual parents. American Journal of Orthopsychiatry. 77(4): 550-562. DOI: 10.1037/0002-9432.77.4.550.

Goldberg A. 2010. Lesbian and Gay Parents and Their Children: Research on the Family Life Cycle. American Psychological Association: Washington DC.

Golombok S, Badger S. 2010. Children raised in mother-headed families from infancy: a follow-up of children of lesbian and single heterosexual mothers, at 
early adulthood. Human Reproduction 25(1): 150-157. DOI:10.1093/humrep/dep345

Hargreaves K. 2006. Constructing Families and Kinship Through Donor Insemination. Sociology of Health \& Illness 28(3): 261-283. DOI: 10.1111/j.14679566.2006.00492.x

ISTAT. 2012. La popolazione omosessuale nella società italiana. Available at http://www.istat.it/it/archivio/62168 (accessed 7 September 2015).

ISTAT. 2014. Le nuove informazioni del $15^{\circ}$ Censimento della popolazione e delle abitazioni Available at http://www.istat.it/it/archivio/124394 (accessed 7 September 2015).

Kellett M. 2005. Children as active researchers: a new research paradigm for the $21^{\text {st }}$ century? NCRM Methods Review Papers NCRM/003. ESRC National Centre for Research Methods

Lalli C. 2008. Buoni genitori. Storie di mamme e di papà gay Il Saggiatore: Milano.

Leddy A, Gartrell N, Bos H. 2012. Growing Up in a Lesbian Family: The Life Experiences of the Adult Daughters and Sons of Lesbian Mothers. Journal of GLBT Family Studies 8(3): 243-257. DOI: 10.1080/1550428X.2012.677233

Liamputtong P. 2007. Researching the vulnerable. Sage: London.

Lubbe C. 2008. The experiences of growing up in lesbian-headed families in South Africa. Journal of GLBT Family Studies 4(3): 325-359. DOI: $10.1080 / 15504280802177540$

Lycett E, Daniels K, Curson R, Golombok S. 2005. School-aged children of donor insemination: a study of parents' disclosure patterns. Human Reproduction 20(3): 810-819. DOI: 10.1093/humrep/deh703

Malmquist A, Möllerstrand A, Wikiström M, Zetterqvist Nelson K. 2014. 'A daddy is the same as a mummy': Swedish children in lesbian households talk about fathers and donors. Childhood 21(1): 119-133. DOI: $10.1177 / 0907568213484342$

Morgan M, Gibbs S, Maxwell K, Britten N. 2002. Hearing children's voices: methodological issues in conducting focus groups with children aged 7-11 years. Qualitative Research 2(1): 5-20. DOI: 10.1177/1468794102002001636

Moore MR. 2011. Invisible Families. Gay Identities, Relationships, and Motherhood among Black Women. University of California Press: Berkeley.

Nordqvist P, Smart C. 2014. Relative Strangers: Family Life, Genes and Donor Conception. Palgrave MacMillan.

Perlesz A, Brown R, Lindsay J, McNair R, de Vaus D, Pitts M. 2006. Family in transition: Parents, children, and grandparents in lesbian families give meaning to "doing family". Journal of Family Therapy 28(2): 175-199. DOI: 10.1111/j.1467-6427.2006.00345.x

Risé C. 2013. Il padre. Libertà, dono. Edizioni San Paolo: Cinisello Balsamo.

Robitaille C, Saint-Jacques Mc. 2009. Social Stigma and the Situation of Young People in Lesbian and Gay Stepfamilies. Journal of Homosexuality 56(4): 421-442. DOI: 10.1080/00918360902821429

Rosenfeld MJ. 2010. Nontraditional families and childhood progress through school. Demography 47(3): 755-775. DOI: 10.1353/dem.0.0112 
Tasker F. 2010. Same-Sex Parenting and Child Development: Reviewing the Contribution of Parental Gender. Journal of Marriage and Family 72(1): 35-40. DOI: $10.1111 / \mathrm{j} .1741-3737.2009 .00681 . \mathrm{x}$

Tasker F, Granville J. 2011. Children's Views of Family Relationships in Lesbian-Led Families. Journal of GLBT Family Studies 7(1-2): 182-199. DOI: 10.1080/1550428X.2011.540201

Taurino A. 2012. Famiglie e genitorialità omosessuali. Costrutti e riflessioni per la disconferma del pregiudizio omofobico. Rivista internazionale di filosofia $e$ psicologia 3(1): 67-95. DOI: 10.4453/rifp.2012.0008

Vanfraussen K, Ponjeart-Kristoffersen I, Brewaeys A. 2002. What does it mean for youngsters to grow up in a lesbian family created by means of donor insemination? Journal of Reproductive and Infant Psychology 20(4): 237-252. DOI: $10.1080 / 0264683021000033165$

Wardle LD. 1997. The Potential Impact of Homosexual Parenting on Children. University of Illinois Law Review: 833-1199.

Weston K. 1991. Families We Choose: Lesbians, Gays, Kinship. Columbia University Press: New York.

Winter J-P. 2010. Homoparenté. Editions Albin Michel: Paris. 